\title{
Hepatitis-B surface antigen and antibody in Black and White patients with venereal diseases
}

\author{
J. SCHNEIDER, L. KING, G. M. MACNAB, AND M. C. KEW \\ From the Venereal Diseases Clinic and the Department of Medicine, Johannesburg Hospital and \\ University of the Witwatersrand, the Johannesburg City Health Department, and the School of Pathology of \\ the South African Institute for Medical Research and the University of the Witwatersrand, Johannesburg
}

SUMMARY The prevalence of both the hepatitis-B surface antigen (HBsAg) and its specific antibody (anti-HBs) was significantly greater in the sera of White patients suffering from sexually transmitted diseases than that in White blood donors. However, Black patients with venereal diseases did not show an increased prevalence of either HBsAg or anti-HBs. These findings support the view that heterosexual transmission of the hepatitis-B virus is less likely to occur in populations in whom this infection is largely acquired before the age of sexual maturity.

\section{Introduction}

One of the many important new facts to emerge about virus hepatitis type-B since the discovery of the hepatitis-B surface antigen (HBsAg) is the frequency with which the disease is transmitted by non-parenteral routes. Unfortunately, the exact routes and their relative importance remain uncertain. Particularly confusing at present is the role played by sexual contact in the spread of the hepatitis-B virus (HBV). HBsAg has been demonstrated in the semen (Heathcote et al., 1974; Linnemann and Goldberg, 1974) and vaginal secretions (Darani and Gerber, 1974) of individuals with HBs antigenaemia. However, while an increased prevalence of HBsAg and its specific antibody (antiHBs) has consistently been found in the sera of patients attending venereal disease clinics (Fulford et al., 1973; Jeffries et al., 1973; Szmuness et al., 1975; Vranckx, 1975), studies in prostitutes have yielded conflicting results (Adam et al., 1974; Papaevangelou et al., 1974; Frösner et al., 1975). Moreover, investigation of the families of chronic carriers of HBV has usually failed to show a higher prevalence of $\mathrm{HBsAg}$ in spouses than in other family members (Berris et al., 1973; Szmuness et al., 1973; de la Concha et al., 1974), suggesting that heterosexual intercourse may not be an important

Address for reprints: Dr M. C. Kew, Department of Medicine, Witwatersrand University Medical School, Hospital Hill, Johannesburg 2001, South Africa

Received for publication 24 June 1977 means of transmission. In spite of this confusion, there seems little doubt that homosexual, particularly anal, transmission is important (Fulford et al., 1973; White et al., 1974; Szmuness et al., 1975).

One possible explanation for the inconclusive results on heterosexual transmission of the virus has been suggested by Frösner et al. (1975) namely, that sexual transmission may be more important in highly developed countries with a low chronic HBV carrier rate and where HBV infection is mainly acquired in adult life. White South Africans are known to have a low prevalence of HBs antigenaemia, while the Blacks have a high prevalence (Bersohn et al., 1974) and the infection is acquired mainly during childhood and adolescence, before sexual activity starts (Macnab et al., 1977, unpublished data). We have been able to study individuals with venereal diseases from these two populations. We report here our findings.

\section{Materials and methods}

Sera from 473 White and 227 Black patients attending a venereal disease clinic in Johannesburg were tested for the presence of $\mathrm{HBsAg}$ and antiHBs. Over $50 \%$ of the Black patients were suffering from syphilis (usually primary, but in some cases secondary or latent) and $20 \%$ had gonococcal or non-gonococcal urethritis. Urethritis (gonococcal or non-gonococcal) was present in two-thirds of the White patients and syphilis in only a small percentage. In some patients more than one venereally 
transmitted disease was present. No attempt was made to consider the venereal diseases separately in respect to the presence of $\mathrm{HBsAg}$ and anti-HBs. Apparently healthy voluntary blood donors were used as controls; there were 2460 White controls and 1200 urban Black controls.

HBsAg was detected in the serum by solid-phase radioimmunoassay using the Ausria $\mathbf{I I}-\mathrm{I}^{125}$ test (Ling and Overby, 1972). All positive results were confirmed by using the neutralising antibody technique (Prince et al., 1973). Anti-HBs was detected by both passive haemagglutination (Vyas and Shulman, 1970) and radioimmunoassay (Ginsberg et al., 1973).

The data were analysed statistically using the $\chi^{2}$ test.

\section{Results}

The prevalence of HBsAg and anti-HBs in the White and Black patients with venereal diseases and in the White and Black blood donors is shown in the Table. The difference in the prevalence of HBsAg between the White patients and the White controls was significant $\left(\%_{1}^{2}=6.80, P<0.01\right)$, as was the difference in the prevalence of anti-HBs $\left(\varkappa_{1}^{2}=9.03, P<0.01\right)$. The differences in the prevalence of HBsAg and anti-HBs between the Black patients and Black blood donors were not significant (HBsAg: $\chi_{1}^{2}=1 \cdot 16, \quad \mathrm{P}>0.05$; anti-HBs: $\left.\%_{1}^{2}=2 \cdot 67, \quad \mathrm{P}>0.5\right)$.

Table The prevalence of HBsAg and anti-HBs in White and Black patients with venereal diseases and in White and Black blood donors

\begin{tabular}{|c|c|c|c|c|}
\hline & \multicolumn{2}{|l|}{ Whites } & \multicolumn{2}{|l|}{ Blacks } \\
\hline & $\begin{array}{l}H B s A g \\
(\%)\end{array}$ & $\begin{array}{l}\text { Anti-HBs } \\
(\%)\end{array}$ & $\begin{array}{l}H B s A g \\
(\%)\end{array}$ & $\begin{array}{l}\text { Anti-HBs } \\
(\%)\end{array}$ \\
\hline $\begin{array}{l}\text { Venereal } \\
\text { diseases }\end{array}$ & $\begin{array}{l}0 \cdot 85 \\
(4 / 473)\end{array}$ & $\begin{array}{l}8 \cdot 9 \\
(42 / 473)\end{array}$ & $\begin{array}{l}3 \cdot 1 \\
(7 / 227)\end{array}$ & $\begin{array}{l}32 \cdot 6 \\
(74 / 227)\end{array}$ \\
\hline Blood donors & $\begin{array}{l}0 \cdot 16 \\
(4 / 2460)\end{array}$ & $\begin{array}{l}5 \cdot 3 \\
(131 / 2460)\end{array}$ & $\begin{array}{l}4 \cdot 1 \\
(49 / 1200)\end{array}$ & $\begin{array}{l}27 \cdot 2 \\
(327 / 1200)\end{array}$ \\
\hline
\end{tabular}

The number of positive results and the total number of individuals in each group is given in parentheses.

The number of homosexual patients in both the White and Black groups was small, and was not significantly different in the two groups. The average age of the White patients was $30 \cdot 1$ years and of the Black patients $31 \cdot 6$ years.

\section{Discussion}

The HBV carrier state is common in southern African Blacks (Bersohn et al., 1974), prevalences of up to $16 \%$ being recorded by counter immunoelectrophoresis in some rural areas of the sub- continent. The incidence by radioimmunoassay in urban Blacks is 4\% (Macnab and Kew, 1977, unpublished data). As in other African countries (Williams et al., 1973) the infection is acquired largely during childhood (Macnab et al., 1977, unpublished data). By contrast, South African Whites have the same low prevalence of the HBV carrier state as Whites living in North America or England (Bersohn et al., 1974; Kew et al., 1976), and the infection seems to be acquired mainly in adult life. Frösner et al. (1975) have suggested that transmission of HBV by sexual contact may be more important in more sophisticated populations in which the infection is likely to be acquired during adult life. Our finding of a significantly greater prevalence of HBV infection in White patients with venereal diseases when compared with White blood donors but not in Black patients with similar diseases compared with Black blood donors lends support to this view.

Other explanations for the different findings in the two racial groups must be considered. Male homosexuals appear to be at high risk from acquiring HBV infection as a result of sexual contact (Fulford et al., 1973; White et al., 1974; Szmuness et al., 1975) (although this may be a function only of promiscuity), and different numbers of such individuals may have been present in the groups studied. Only a small proportion of the patients admitted to being homosexual, and the numbers were similar in Whites and Blacks. As the prevalence of anti-HBs in a population increases with age, different age structures of the patients with venereal diseases in comparison with blood donors might offer another explanation. Although the exact ages of the blood donors used as the control groups in the present study were not analysed, the average age of the White patients was 30 years and that of the Black patients 31 years, and it is very unlikely that the average age for the blood donors was less than this. Kačaki et al. (1975) reported a higher prevalence of HBs antigenaemia in patients with syphilis than in those with gonorrhoea. A different pattern of sexually transmitted diseases was present in the two racial groups studied, syphilis being far more common and gonorrhoea infection far less common in the Blacks than in the Whites. This pattern of venereal disease would favour a higher incidence of $\mathrm{HBV}$ infection in the Black patients as compared with Black controls than in the White patients compared with their controls. The fact that we found the opposite strengthens the argument that HBV infection is less likely to be transmitted by sexual contact in less sophisticated populations in whom the infection has almost always been acquired before the age of sexual maturity. 


\section{References}

Adam, E., Hollinger, F. B., Melnick, J. L., Duenas, A., and Rawls, W. E. (1974). Type B hepatitis antigen and antibody among prostitutes and nuns: a study of possible venereal transmission. Journal of Infectious Diseases, 129, 317-321.

Berris, B., Wrobel, D. M., Sinclair, J. C., and Feinman, S. V. (1973). Hepatitis-B antigen in families of blood donors. Archives of Internal Medicine, 79, 690-693.

Bersohn, I., Macnab, G. M., Pyzikowska, J., and Kew, M. C. (1974). The prevalence of hepatitis-B (Australia) antigen in southern Africa. South African Medical Journal, 48, 941-944.

Darani, M., and Gerber, M. (1974). Letter: Hepatitis-B antigen in vaginal secretions. Lancet, $2,1008$.

de la Concha, E. G., Masllorens, F. O., and Hernándes-Guio, C. (1974). Letter: Frequency of hepatitis-B antigen or antibody in household contacts of HBAg carriers. Lancet, 2, 1267-1268.

Frösner, G. G., Buchholz, H. M., and Gerth, H. (1975). Prevalence of hepatitis-B antibody in prostitutes. American Journal of Epidemiology, 102, 241-250.

Fulford, K. W. M., Dane, D. S., Catterall, R. D., Woof, R., and Denning, J. V. (1973). Australia antigen and antibody among patients attending a clinic for sexually transmitted diseases. Lancet, 1, 1470-1473.

Ginsberg, A. L., Conrad, M. E., Bancroft, W. H., Ling, R. M., and Overby, L. R. (1973). Antibody to Australia-antigen: detection with a simple radioimmunoassay. Incidence in military populations and role in the prevention of hepatitis-B with gammaglobulin. Journal of Laboratory and Clinical Medicine, 82, 317-325.

Heathcote, J., Cameron, C. H., and Dane, D. S. (1974). Hepatitis-B antigen in saliva and semen. Lancet, 1, 71-73.

Jeffries, D. J., James, W. H., Jefferiss, F. J. G., MacLeod, K. G., and

Willcox, R. R. (1973). Australia (hepatitis-associated) antigen in patients attending a venereal diseases clinic. British Medical Journal. $2,455-456$.

Kačaki, J., Schuurs, A. H. W. M., Wolters, G., and Lalosević, J. (1975). Letter: Hepatitis-B antigen in venereal diseases. Lancet, 2. 363-364.
Kew, M. C., MacKay, M. E., Mindel, A., Joffe, B. I., Kusman, B., Macnab, G. M., and Seftel, H. C. (1976). Prevalence of hepatitis-B surface antigen and antibody in white and black patients with diabetes mellitus. Journal of Clinical Microbiology, 4, 467-469.

Ling, C. M., and Overby, L. R. (1972). Prevalence of hepatitis-B virus antigen as revealed by direct radioimmunoassay with $125 \mathrm{I}$ antibody. Journal of Immunology, 109, 834-841.

Linnemann, C. C., and Goldberg, S. (1974). Letter: Hepatitis-B antigen in saliva and semen. Lancet, $1,320$.

Papaevangelou, G., Trichopoulos, D., Kremastinou, T., and Papoutsakis, G. (1974). Prevalence of hepatitis-B antigen and antibody in prostitutes. British Medical Journal, 2, 256-258.

Prince, A. M., Brotman, B., Jass, D., and Ikram, H. (1973). Specificity of the direct solid-phase radioimmunoassay for detection of hepatitis-B antigen. Lancet, 1, 1346-1350.

Szmuness, W., Much, I., Prince, A. M., Hoofnagle, J. M., Cherubin, C. E., Harley, E. J., and Block, G. H. (1975). On the role of sexual behavior in the spread of hepatitis-B infection. Annals of Internal Medicine, 83, 489-495.

Szmuness, W., Prince, A. M., Hirsch, R. L., and Brotman, B. (1973). Familial clustering of hepatitis-B infection. New England Journal of Medicine, 289, 1162-1166.

Vranckx, R. (1975). Letter: Hepatitis-B antigen and serological evidence of syphilis. Lancet, $1,1193$.

Vyas, G. H., and Shulman, H. R. (1970). Haemagglutination assay for antigen and antibody associated with viral hepatitis. Science, 170, 332-333.

White, E., Rudikoff, D., and Kaufman, A. (1974). Hepatitis as a venereal disease in homosexuals. New England Journal of Medicine, $290,1384$.

Williams, A. O., Fabiyi, A., Williams, A. I. O., Gupta, B., O'Connor, E. H., and Greenwood, B. M. (1973). Hepatitis-B antigen in Nigerian children. East African Medical Journal, 50, 521-529. 